\title{
月七年六十二治 明
}

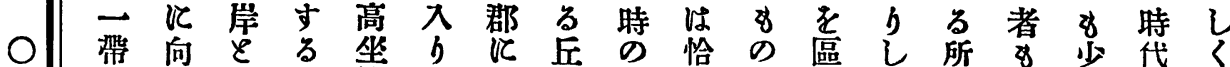

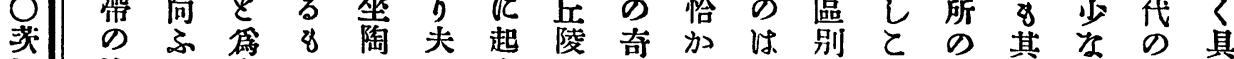

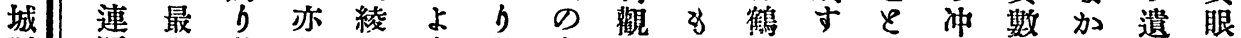
鲧 脉 8 其 其 の $b$ 其 向 想岬見机推 洪多 ら靕 の

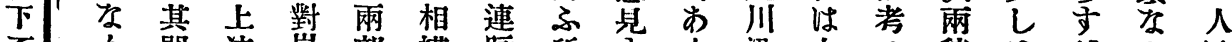
石 b 間 流岸 部摸 脉 所要 b 沿大 世積

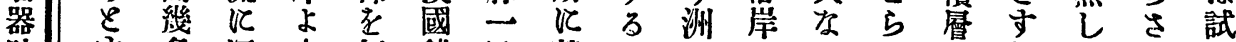

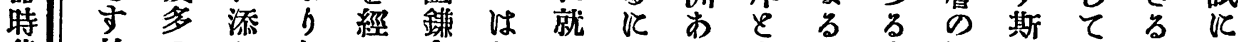

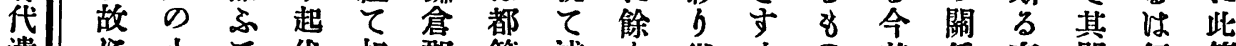
遺 『 小て 伏 相 郡 筑 述

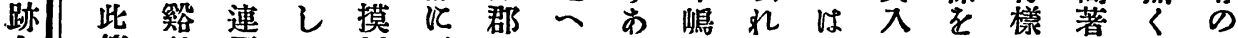
七 等 谷亘て 川 所

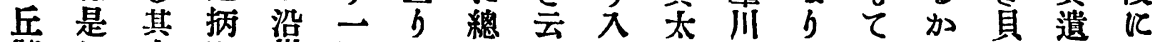

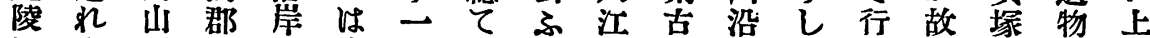

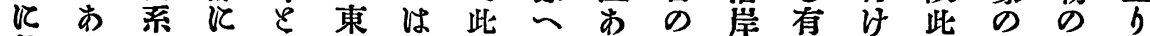

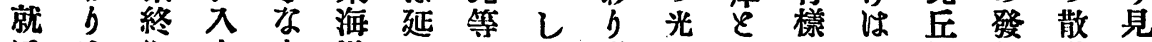

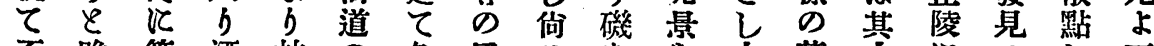

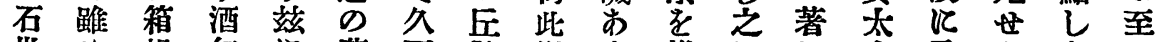

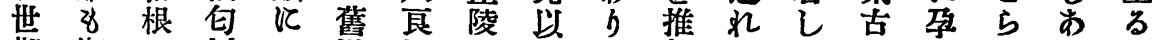
期 概の 川

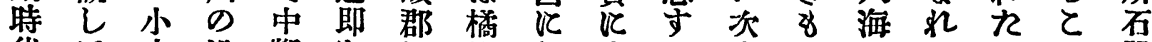

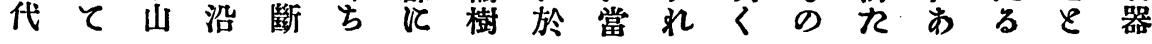

$=\pi$ 就 載 $ッ ⿻ 上 丨$

係途 $キ$ 大 $大$ 貝城

》中

何 $=$ 眼前塚

$\nu$ 發 $ᄌ$, 發四、石城

モ見ル本掘月到器 縣

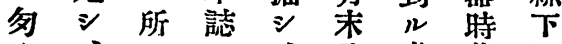

名: $>$ 入

畧或 $\Rightarrow$ 在益极, 㗊

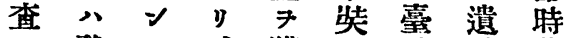

潑、、獲至丘跡代

去掘 $\pi$ 由 $刃$ 郎 $=$ 遺

リノく ル君積富跡

シ 餘但爻 7雪ミ七

四 人時 シ 效勘共, 夕所

二 = 偷等 他 $\ni$ 同留地下

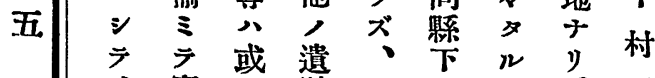

、實 或遺其椎 》

事踐椎地報塚如而四

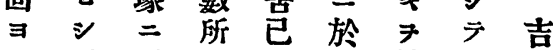

》所至二三貝殊
員り期 厄緒連發の 諸故特情学絡見邀 君 代 以 發 の方靕 の前の远部るを 泩記遗述し洛所探 意を物ふ得をの究

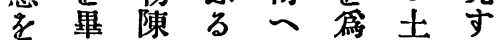
請る 列所き世器れ は所の所しの忟 さ臨五原の \& み 云陵

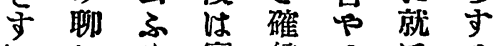
ᄂ 加 8 實 信 $\varepsilon$ と 思决江主云其 ふし太夫 ふ赤連 小て 古和起其 絡 し過の 如を當を を释 遗 斯 \& 時 明 浗に靕 量知の ら 二あ『狀得人加 併 5 しな類に

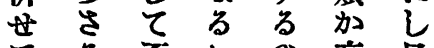
乙方石出交且 會索世 端通つ 
號入十八第瞣雜會學類人京東

此 欲 君 (一) 敬見, 右

七 三 柏 $ァ$ 位 讙

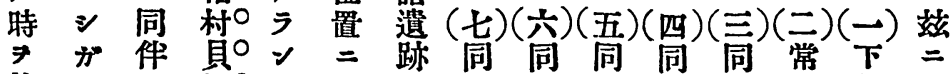

節 及 8 塚 7 就 中

思東 $\neq *$ 本國國國國國感國を

的孧>京四請

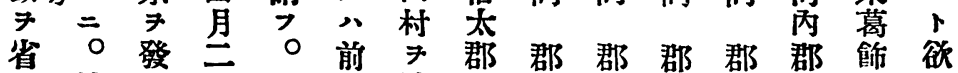

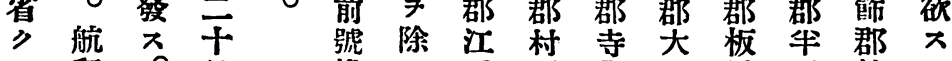

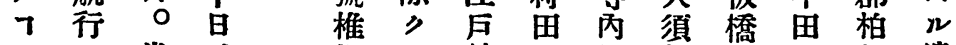

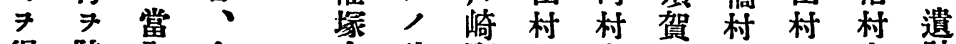

得陸初余令他町字字村字字跡

行汽

シ 二 船 椎

㙈 字白道字 $\exists$

、比 $=$ 增

然 大 搭 介

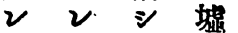

氐該 發

途挂 地 掘

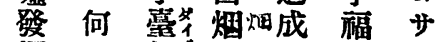

上 左

中心三人

掘 $v$ 畑各及寺思门

㨬則赴篇

報飞”野畑

告 貝

附榐

畑

于

$\Xi$

及 所

下 ナ

于 y

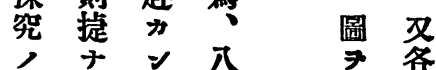

ゴ

便り、亣

參 所

ル群

₹ 細

無 亘

用 亘

$=F$

P 得

サ 得 石

卜 器

踓 時

シ

粗其 造

漏 狀

, 呪所

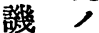

$\therefore \rightarrow$

甘 斑

; 7

テ 諸

受 君

$\Rightarrow=$

紹

所尔

$+\pi$

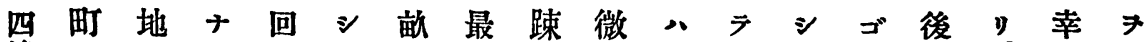

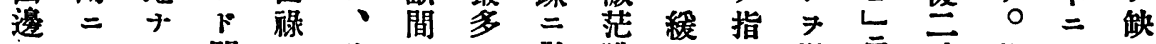

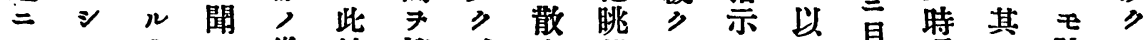

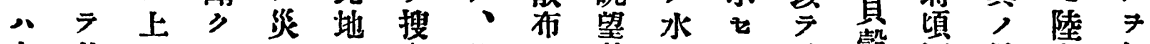

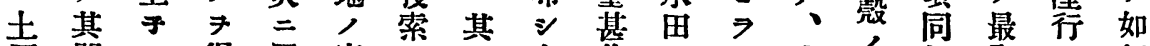
石間 ゴ得罹字七>士佳二

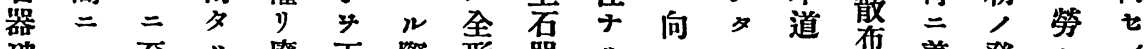

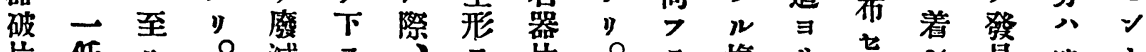
片 低出 0 隇子

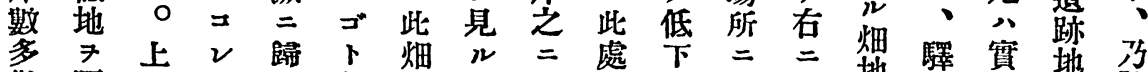

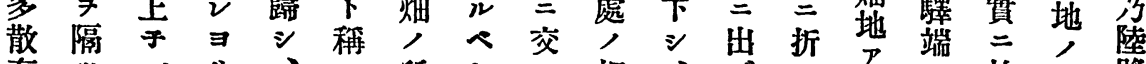

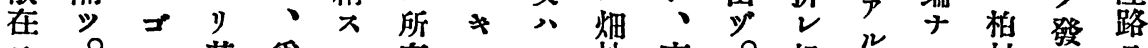
ス 0 其第

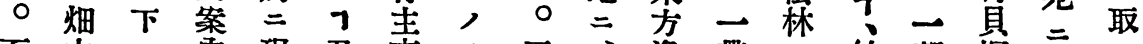

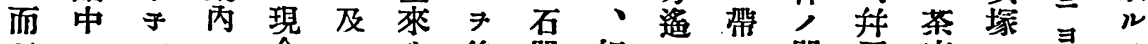

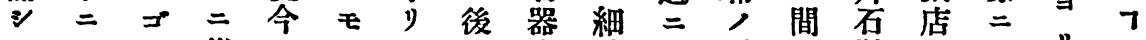

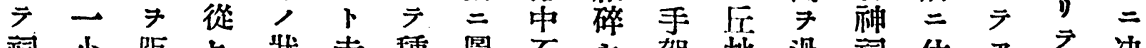

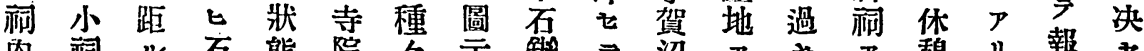

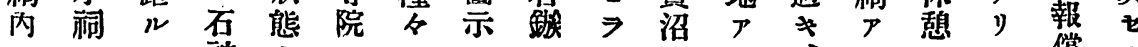

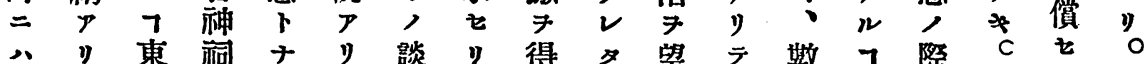

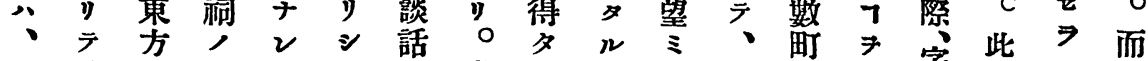
榞 其五在 7 、 


\section{月七年六十二治明}

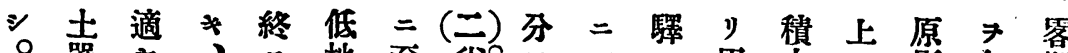

○器七、二地至乎学

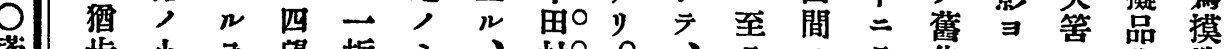

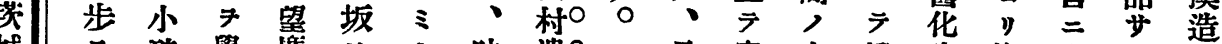

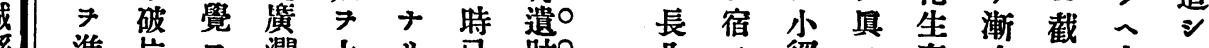

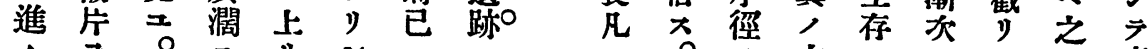

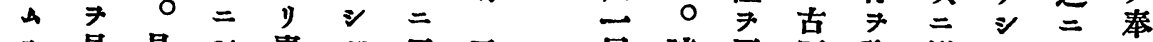

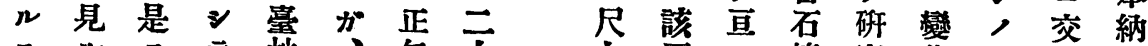

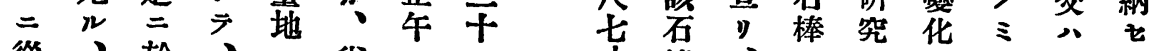

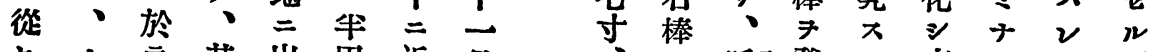

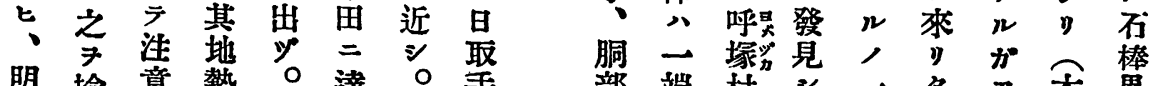

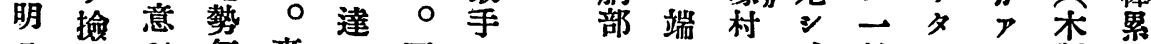

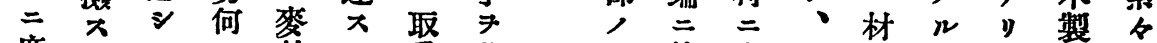
席几

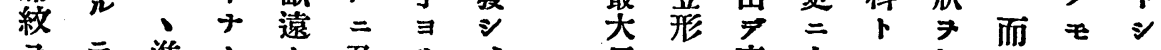

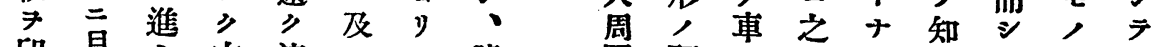

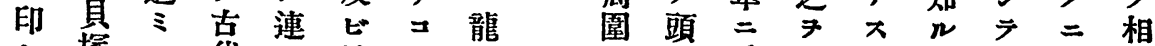
七塚 シ 代ナ足、ガ 声 $=$ 人 $y$ 指 二 崎

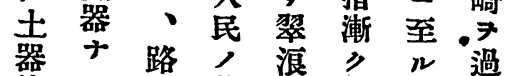

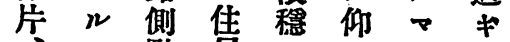
凡 尺 粗 製 尺四製 暮 岳 等

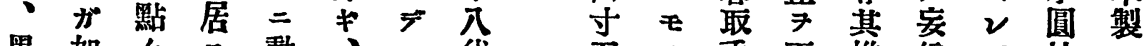
黑如々

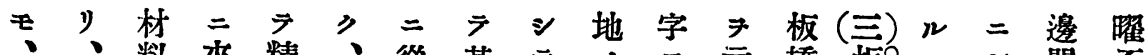

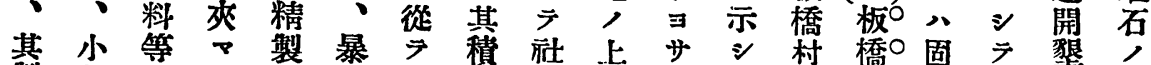

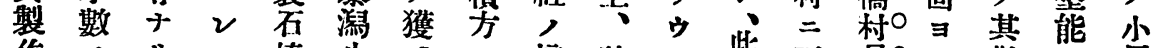

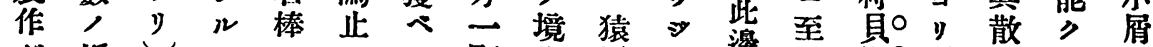
が探

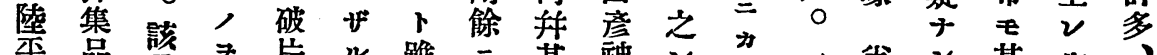
具 管得長

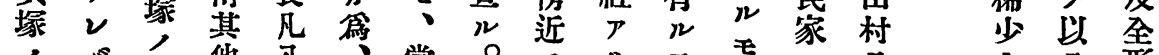

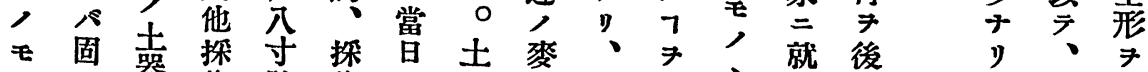
, $\exists$ 集 吘 集 朝 器 嘼 巨知出

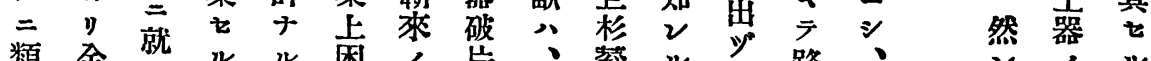

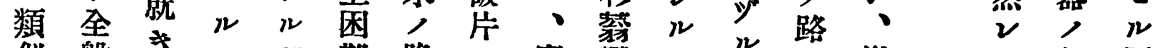

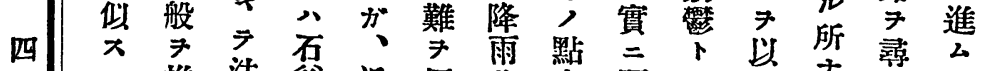

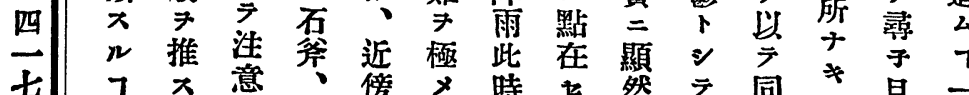
7 意、傍 $>$ 特七然

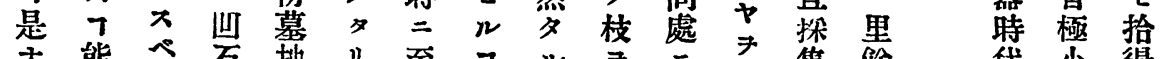

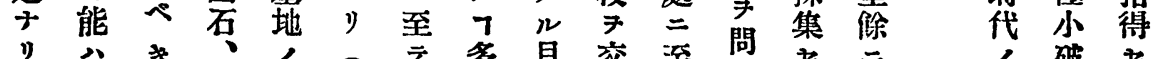
》小

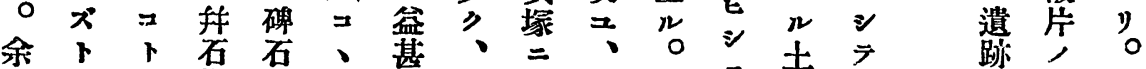

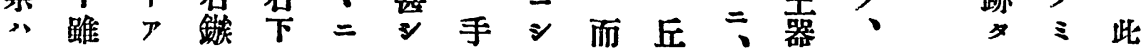


號入十八第詰雜會學類人京東

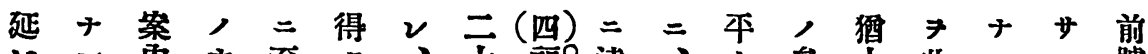

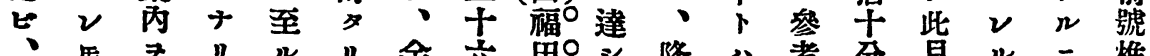

南共

方二賴 余所 万椎全貝宿猶距ナ查

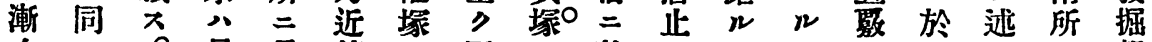

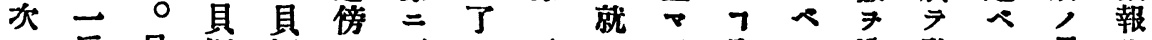

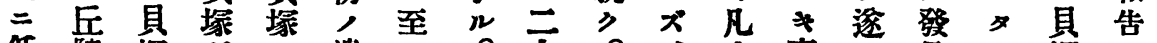

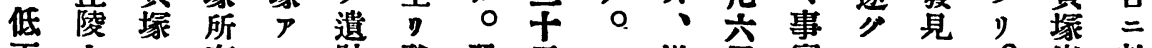

下上 $心$ 在》跡發翌三道里實 $\nu$ 七 出於

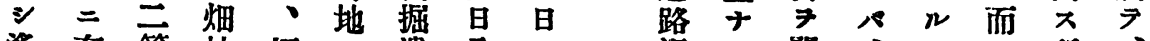

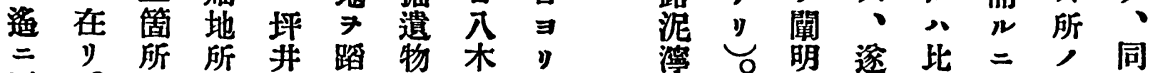

平 $0=$ 有 香 $>$ 君椎 学

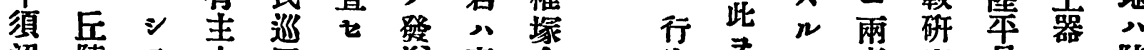

沼陵

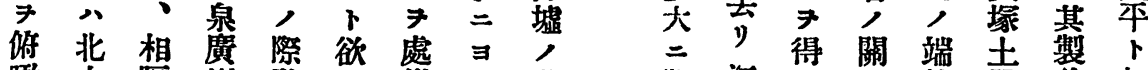

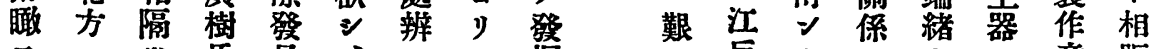

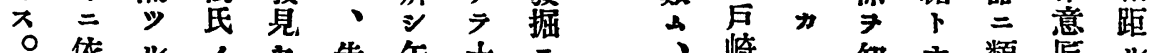

兩俄

貝東三三 $三$ 䕐少三事向橋大へル上遠

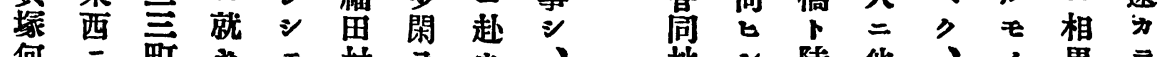

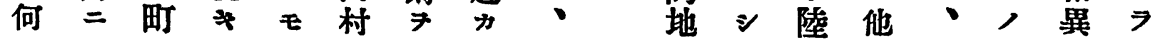

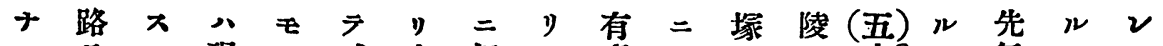

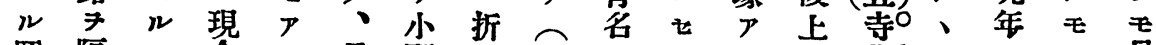

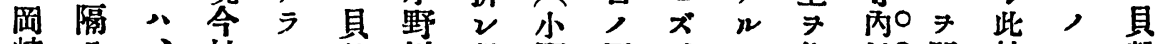

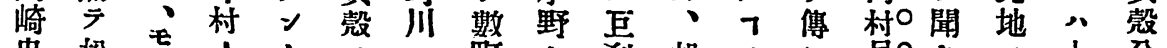

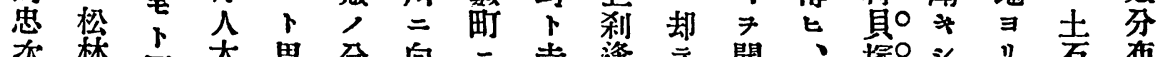

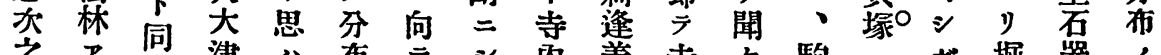

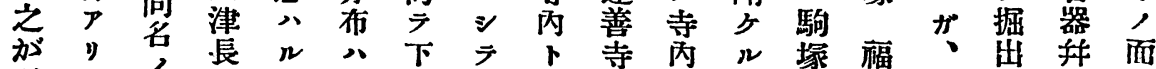
所 $三$ 寺兵、極

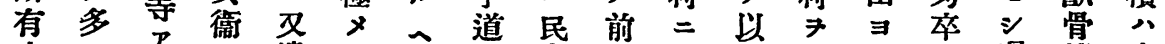

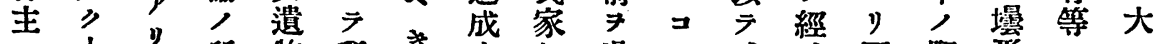

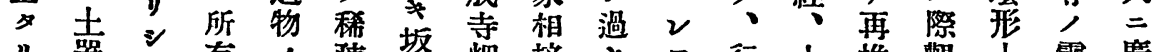

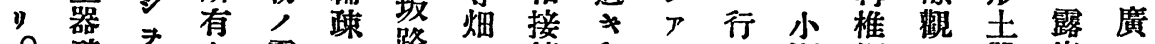

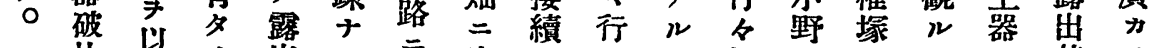

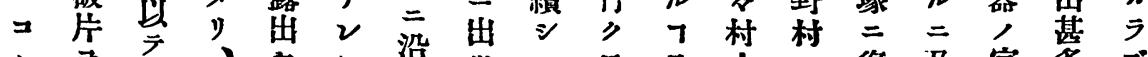
、 7 、

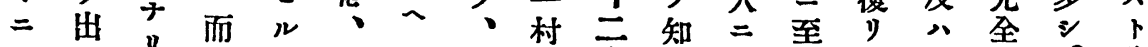

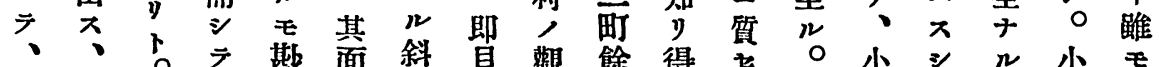

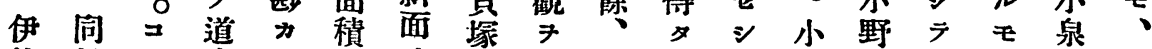

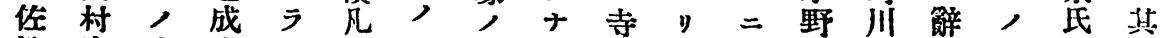
津字南寺 $大$ 方麥在 村二方烟。方烟学》村小所三岸去藏宅方

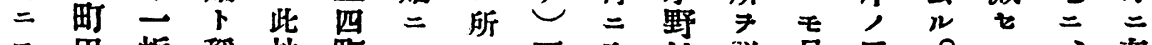
モ田坂稱地町 $シ$ 西入村詳貝丘 $0 \Rightarrow$ 、在 
月七年六十二治明

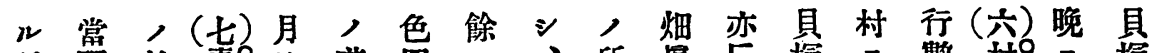

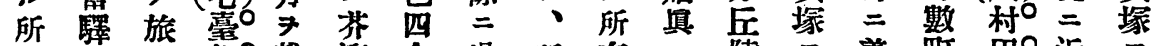
> > 宿 畑。戴溜合過所有二陵 $>$ 着町田近 $>$

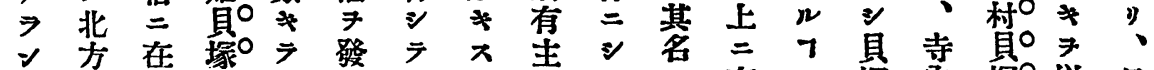
小小方汇掘、、翟、主 妝 即川思干崎、物 器

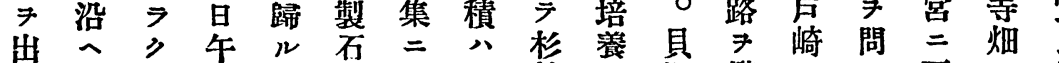

北 $₹$ 方君 端捙石, $\exists$ 系 器 餙

離 女 時 來 $\nu$ 令代

同唒人待 方或遺 千

向八跡 獨 二發甚江

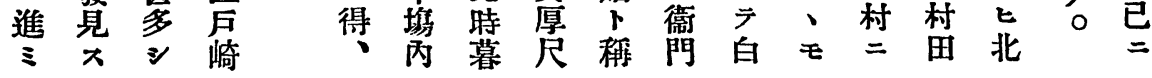
小 $\vec{*}$ 麥, 過两

石以町畑地手 $v$ 聞字渡 $F$ 路 7

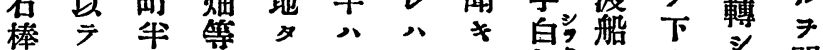

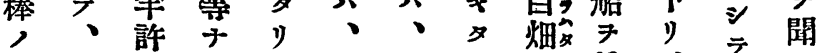
破 鍬 =

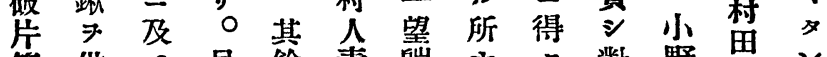

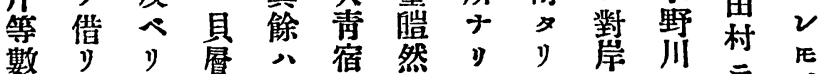
個植 0 小野 新

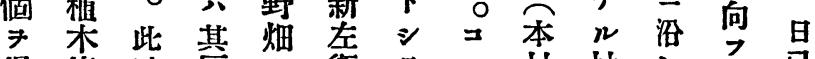

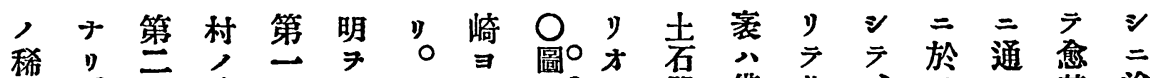

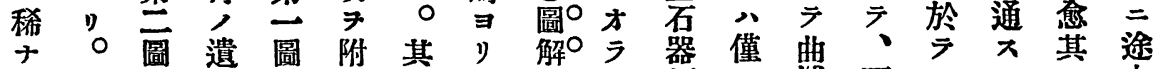

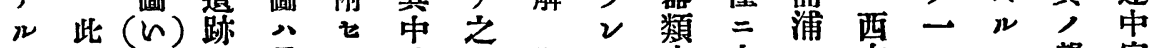
八地了ろ 一方 特

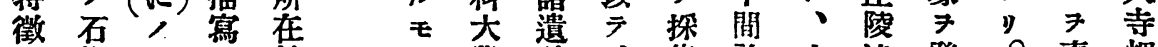
鋔石上地，學跡、集許亦遠發。喜畑

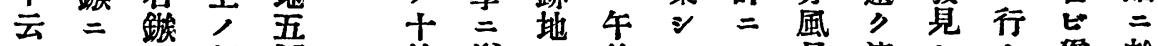

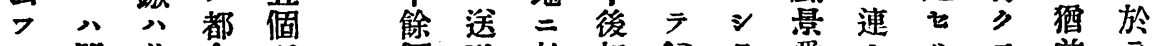

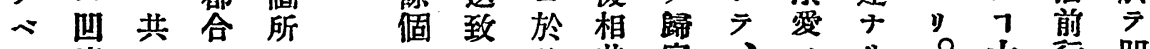

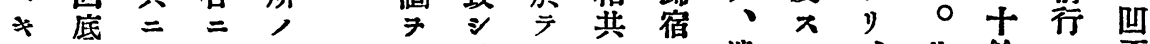

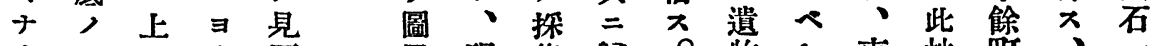

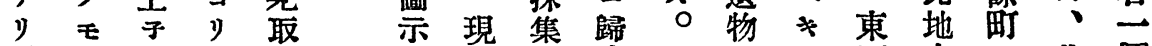
四 (ほ)多 具 そ 二小》垠畧り

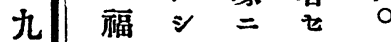
思 $テ$ 村 具有名村 塚柄心 $=>$ 福 テモ, 田 七 七 京八, 一面小二此個

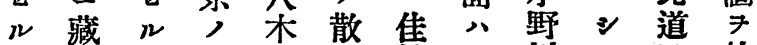
₹ 遺途君布地小川 以 $=$ 物三已 今人 $八$ 就三制》川臨处即七 簡 類、与士合 0 ○ 單學悉り蒲

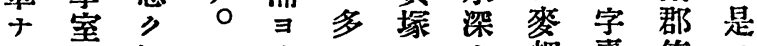

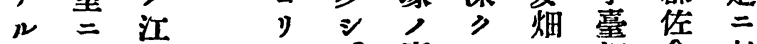
説在甹還。廣入二畑倉於 
躆八十入第䀦雜會悬類人京東

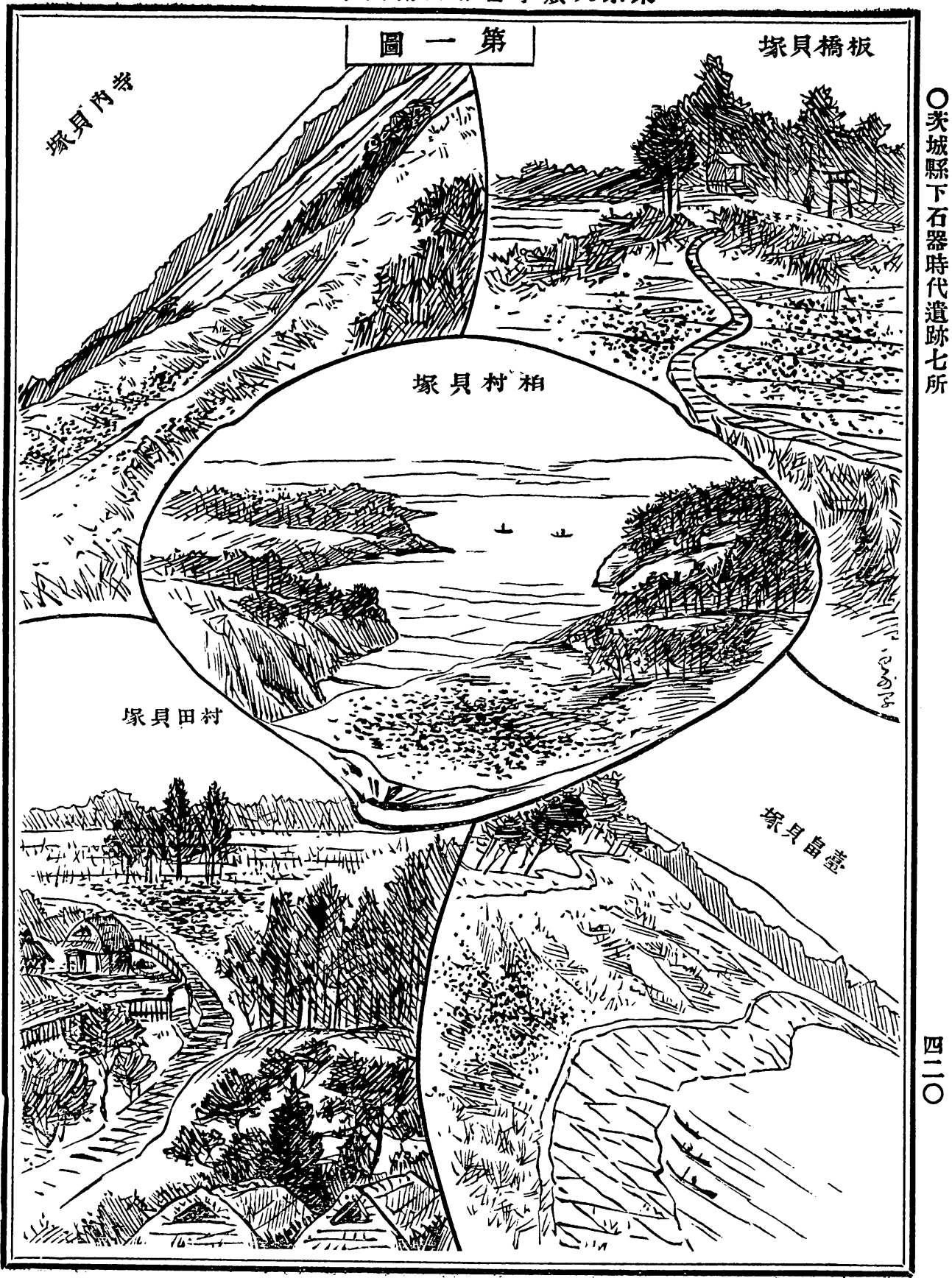




\section{月七年六十二治明}

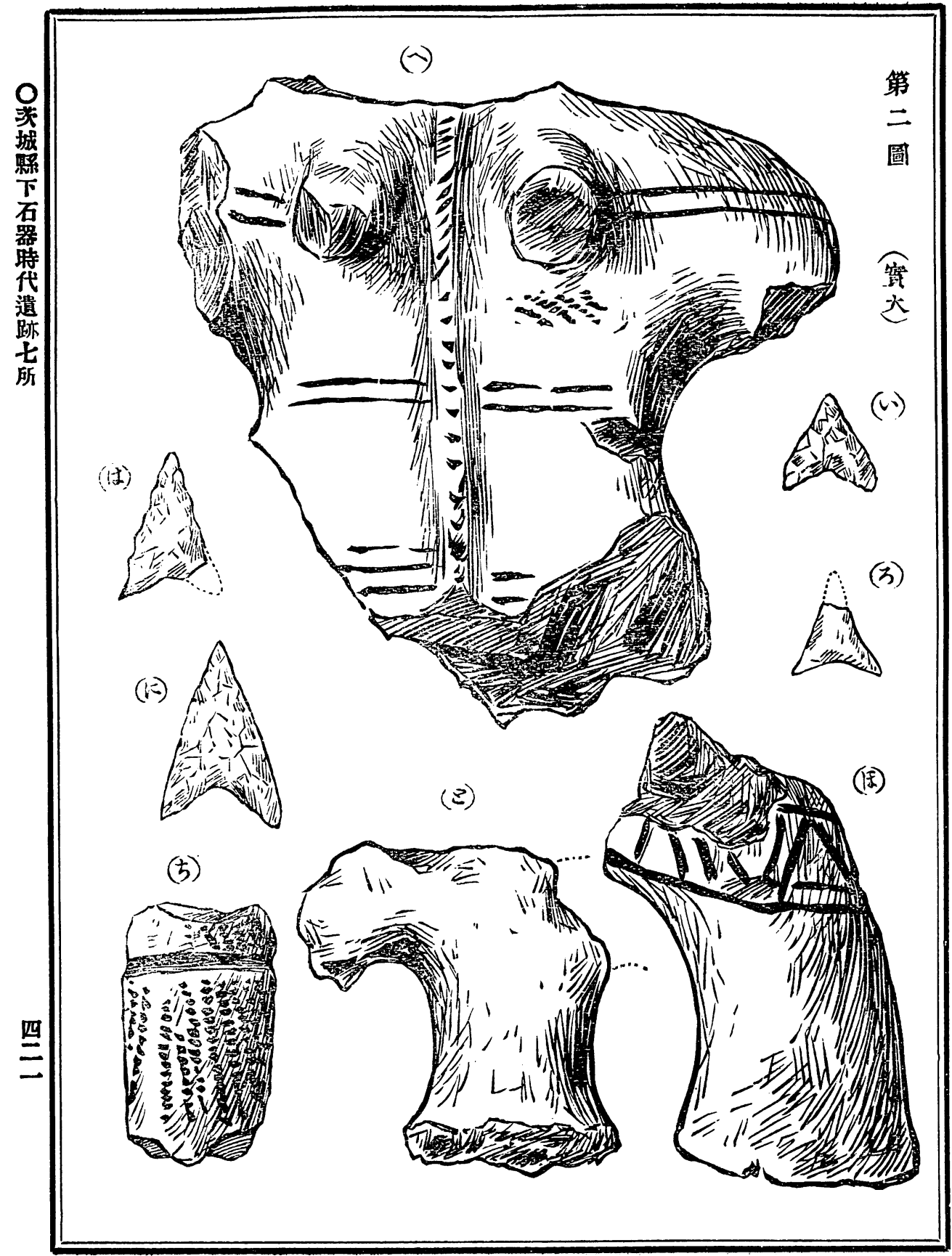


號入十八第鼓雜會學類八京東

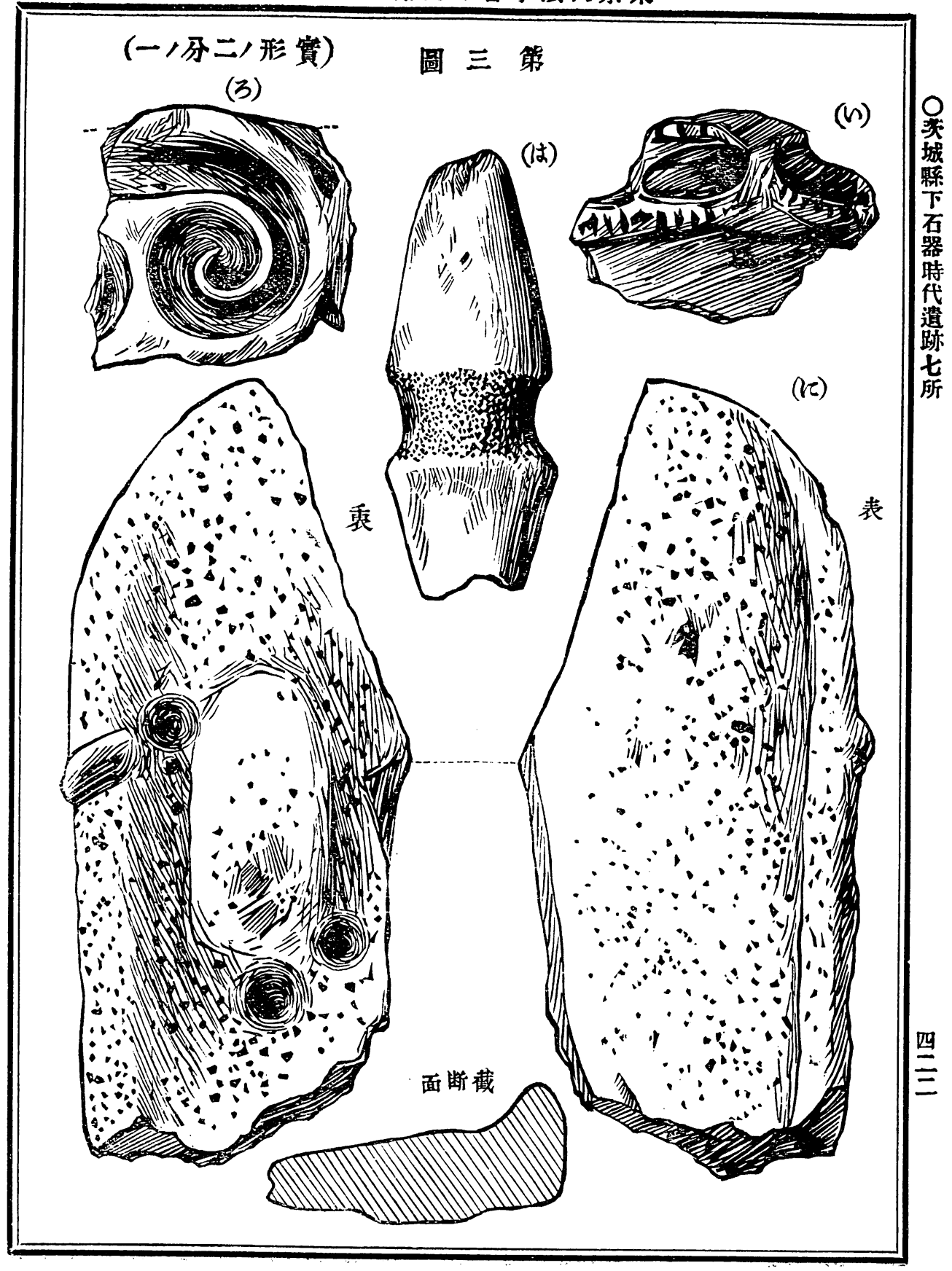




\section{月七年六十二治明}

染
城
縣
石
器
集
遗
跡
皆
所

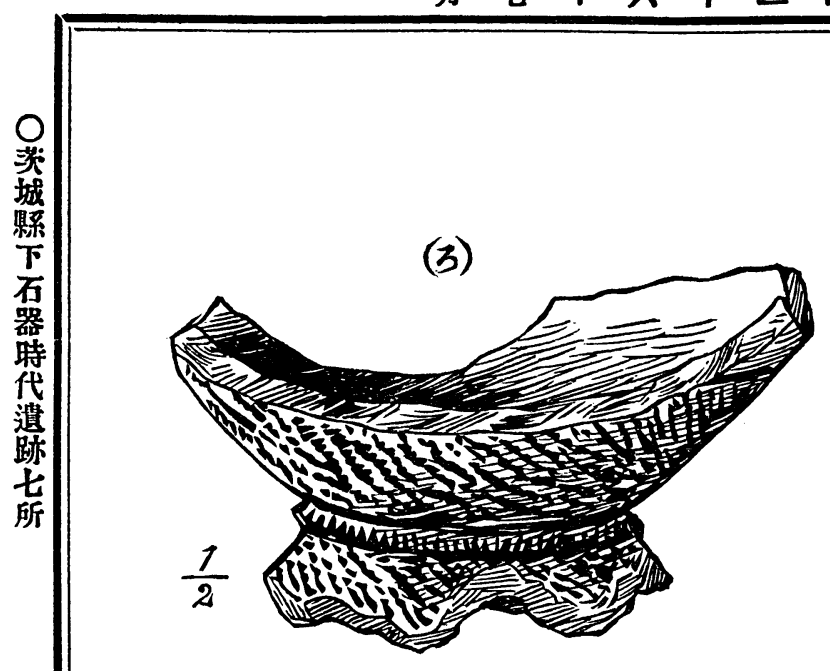

(h)

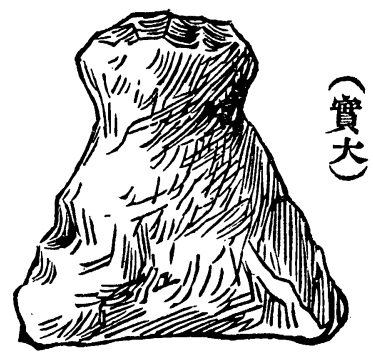

此本氏 氏 年小第能考山有

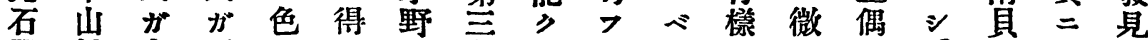

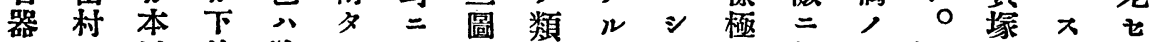

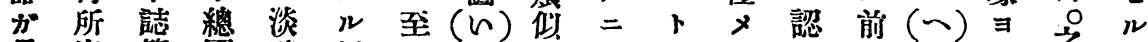
貝出、第國 碧 獨

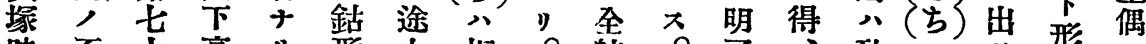

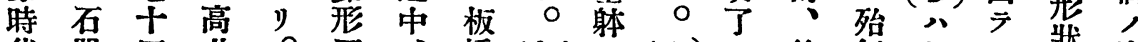
代器四井 0 石、橋 (ち)

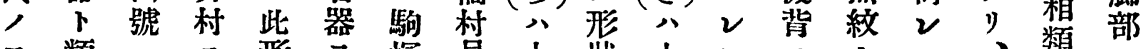
モ類 $\square=$ 形

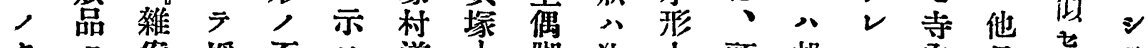
夕夕案 探 石 几 リ

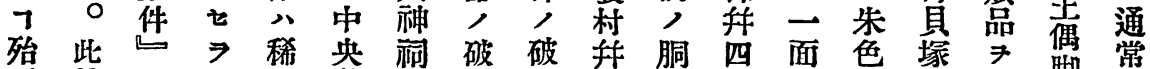

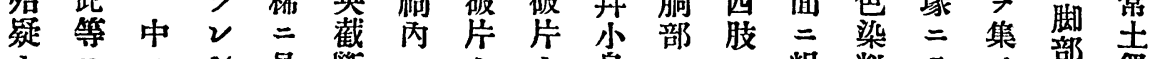

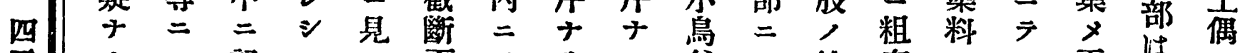

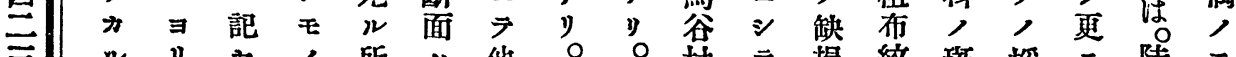

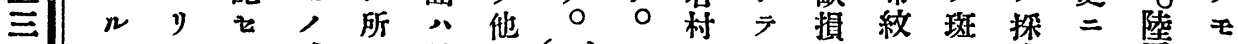

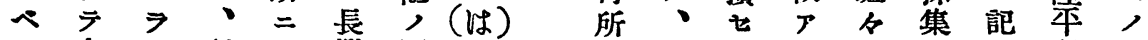

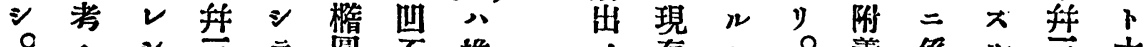

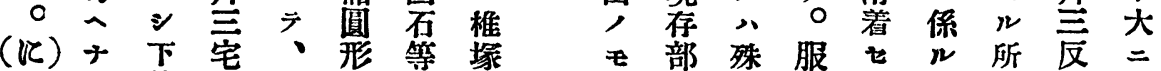

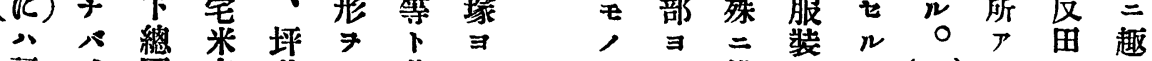
程、國吉井ナ共り 
號入十八第就雜會學颖人京東

\begin{tabular}{|c|c|c|c|c|c|c|c|c|c|c|c|c|c|c|c|c|c|}
\hline 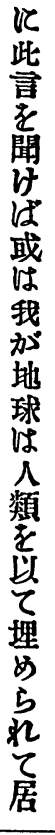 & 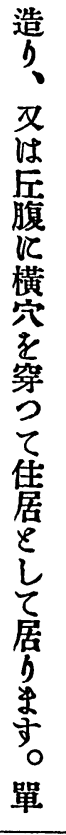 & 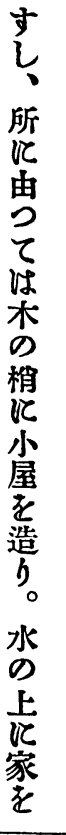 & 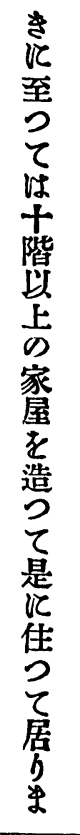 & 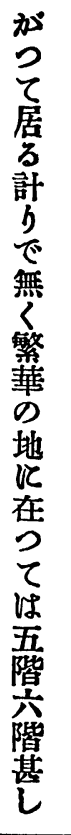 & 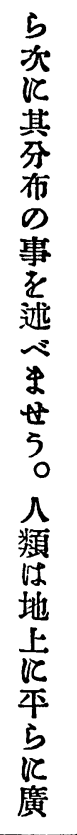 & 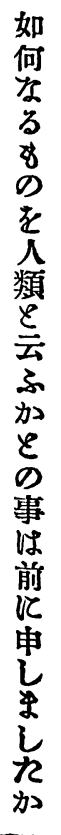 & $\begin{array}{l}\text { 人 } \\
\text { 類 } \\
\text { の } \\
\text { 杂 } \\
\text { 布 } \\
\text { ○ }\end{array}$ & $\begin{array}{l}\text { 理 } \\
\text { 學 } \\
\text { 士 } \\
\text { 坪 } \\
\text { 并 }\end{array}$ & $\begin{array}{c}\text { O } \\
\text { 講通 } \\
\text { 話俗 } \\
\text { 人 } \\
\text { 類 } \\
\text { 學 } \\
\text { 大 } \\
\text { 意 } \\
\text { 續 }\end{array}$ & & 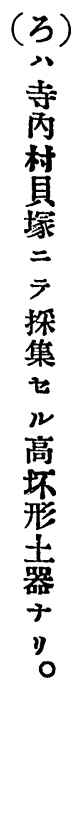 & 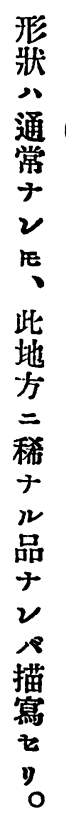 & 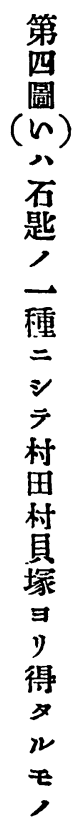 & 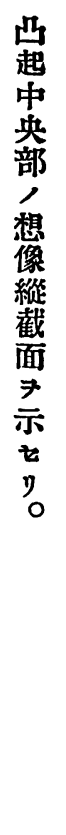 & 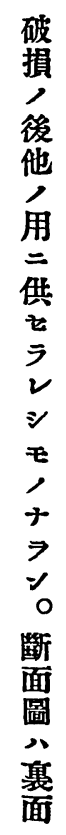 & 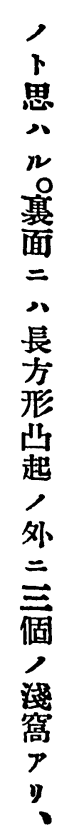 & 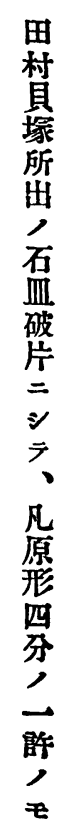 \\
\hline 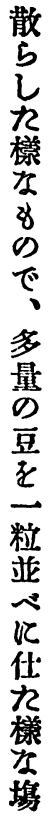 & 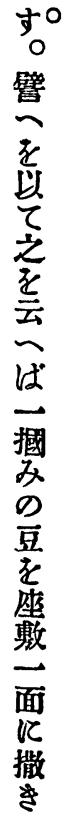 & 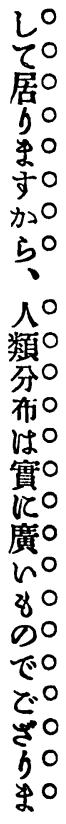 & 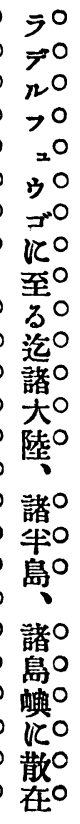 & 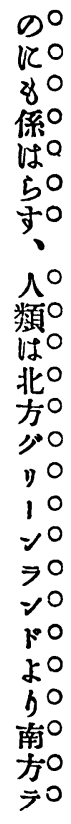 & 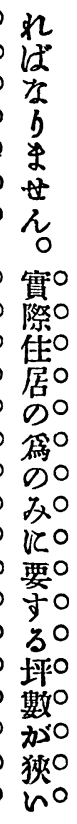 & 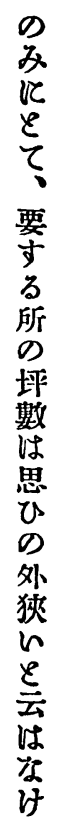 & 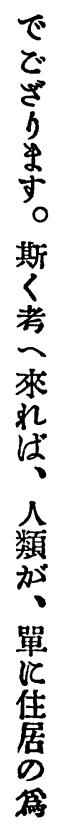 & 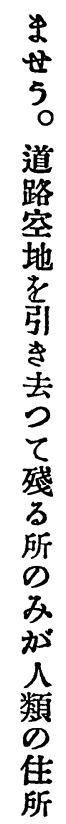 & 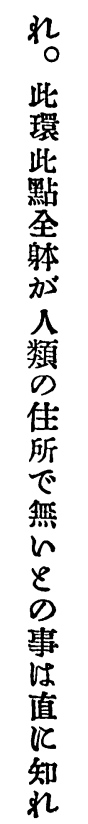 & 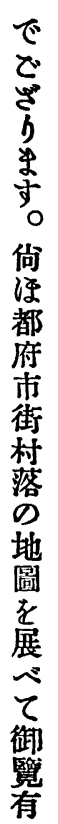 & 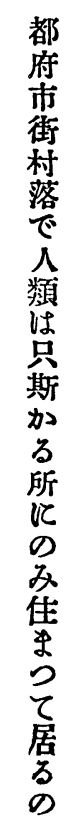 & 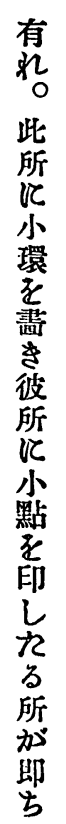 & 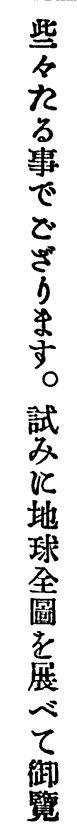 & 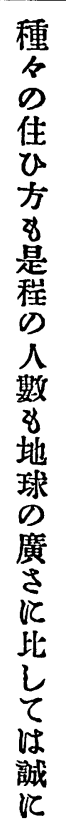 & 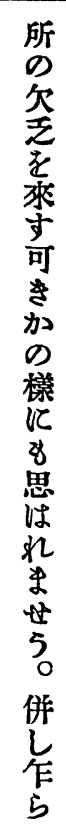 & 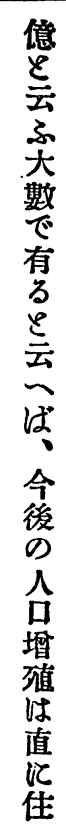 & 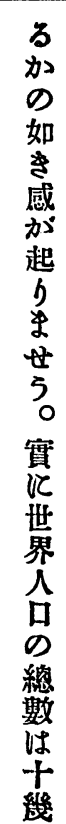 \\
\hline
\end{tabular}

